\title{
Volatility and Causality in Strategic Commodities: Characteristics, Myth and Evidence
}

\author{
Youngho Chang ${ }^{1}$, Zheng Fang ${ }^{1} \&$ Shigeyuki Hamori ${ }^{2}$ \\ ${ }^{1}$ School of Business, Singapore University of Social Sciences, Singapore \\ ${ }^{2}$ Graduate School of Economics, Kobe University, Japan \\ Correspondence: Zheng Fang, School of Business, Singapore University of Social Sciences, 461 Clementi Road, \\ Singapore. Tel: 65-6248-0314. E-mail: fangzheng@ suss.edu.sg
}

Received: May 23, 2017

Accepted: June 22, 2017

Online Published: July 20, 2017

doi:10.5539/ijef.v9n8p162

URL: https://doi.org/10.5539/ijef.v9n8p162

\begin{abstract}
Commodity prices have fluctuated sharply and Brent oil has been considered the most volatile commodity in price. This paper aims to reveal the true characteristics of the price volatility of six commodities, namely, Brent oil, gold, silver, wheat, corn and soybean and to verify the existence of a long-run relationship and causation among each pair of commodity prices. It finds that there has been persistent volatility in prices of all six commodities from 1986 to 2010. Contrary to the common belief, however, Brent oil appears not to be the most volatile in price. Rather the prices of precious metals and agricultural commodities have been more volatile than Brent oil for some time periods. It also finds that there has been a long-run relationship between the prices of Brent oil and soybean, of Brent oil and wheat, and a bilateral causality relationship between them, which implies that there has been a simultaneous impact on the price trajectories of these commodities.
\end{abstract}

Keywords: GARCH, asymmetry, news impact curve, cointegration, Granger-causality

\section{Introduction}

The volatility of oil price has been increasingly gaining attention in both theory and practice. One of the reasons is that crude oil is one of the most traded commodities in the world, and its price is supposedly the most volatile in the market (Regnier, 2007; Verleger, 1993) (Note 1). The dynamics of oil prices have vast impacts on the economy. Since energy commodities are key inputs to a plethora of economic activities, higher crude oil prices will more often than not lead to higher production cost and therefore higher prices of final goods. It will exert significant upward pressure on the consumer price index (CPI) and the result will be a negative impact on economic growth (Jimenez-Rodriguez \& Sanchez, 2005). Therefore, frequent and large magnitude fluctuating oil prices can affect the businesses in any country (both oil-importing and oil-exporting), especially when there is an increasing reliance on oil.

While there is a growing number of studies focusing on trends and volatility behavior of energy commodity prices (for instance, Sadorsky, 2006; Narayan \& Narayan, 2007; Wei et al., 2010; Arouri et al., 2012; Salisu\& Fasanya, 2013), the dynamics of non-oil commodity prices cannot be ignored as well. Take agricultural commodities as an example. On the macroeconomic level, volatility of agricultural commodity prices may have negative impact on growth and poverty and they are very damaging to the poor countries (Ramey \& Ramey, 1995; Rodrick, 1999). On the microeconomic level, volatility may also impact decisions of farmers and governments. A downward fluctuation would be adverse for farmers, but for a consumer, the reverse is true.

Besides, a comparison of the volatility of crude oil prices against three other major groups of commodities, namely, precious metals and agricultural goods, using daily prices is relatively under-explored. The question how oil price volatility compares with price volatility of other commodities is important because the conventional wisdom that crude oil prices are more volatile ever since the oil crisis in 1973 may not stand up to rigorous analysis. If oil price volatility is more severe compared to prices of other commodities, the oil industry is likely to design some special treatments to handle risk and uncertainties. They may find vertical integration that avoids transaction cost more attractive. Or, they may tend to rely more heavily on hedging and long-term contracts. If otherwise, oil price risk may not deserve special attention.

This paper aims to study the price and volatility behavior of three types of strategic commodities using daily 
series covering a period of 1986-2010. First, we will examine whether price shocks have persistent and asymmetric effects on volatility. Following that, we will study whether the conventional wisdom is true across the whole time period examined. Finally, we will look into any correlation or Granger causality relationships between the commodities.

The remainder of this paper is organized as follows. Section 2 reviews the pricing mechanisms and markets of the six commodities. Section 3 critically reviews the related literature on volatility of commodity prices while Section 4 describes the data and methodologies used to model volatility, cointegration and causation amongst the different sub categories of commodities. Section 5 presents the results and Section 6 concludes this study with policy implications.

\section{Background}

As proposed by Plourde and Watkins (1998), comparisons of price volatility across different commodities must heed basic industry pricing mechanisms and market structures. This section reviews pricing mechanisms and markets of the commodities examined in this paper.

The fundamentals of crude oil pricing have transformed radically since 1970s. Prior to 1970s, crude oil price was around US $\$ 3.5$ per barrel and prices were determined largely by the big oil companies. This arrangement changed after the first world oil shock in October 1973 when the Organization of Arab Petroleum Exporting Countries (OAPEC (Note 2)) proclaimed an oil embargo because of the Yom Kippur War (Note 3). During this time, the Organization of Petroleum Exporting Countries (OPEC) was the price setter until early 1980s when market forces began to take over the determination of oil prices. Compounded by the Iraq-Iran conflict, oil prices had spiked up to US $\$ 30$ per barrel by 1981.1983 was a milestone in crude oil price determination as it marks the introduction of New York Mercantile Exchange (NYMEX) of crude oil futures contract trading. Since then, copious market instruments have surfaced to facilitate risk management associated to crude oil price changes. Paradoxically, oil market participants had witnessed a phenomenon of 'volatile' oil prices with the increased reliance on the market mechanisms.

Gold has a long history as currency, reserves and an investment tool. In the $19^{\text {th }}$ century, many European countries implemented the gold standard. After World War II, the United States dollar is pegged to gold at a rate of US\$35 per troy ounce under the Bretton Woods System. The system only ceased after the Nixon Shock in 1971 when the US unilaterally suspended the fungible system between gold and the greenback. In recent times, gold has one of the most popular entities used as investment among all the precious metals. Not only that, gold can be used to hedge or harbor against economic, political or currency crisis. This is because gold is an investment asset which is commonly known as the "safe haven", an asset that investors park their money during financial crisis. Gold trading is done over-the-counter (OTC) and the largest global centre for clearing OTC transactions for gold is London Bullion Market (LBM). Like most commodities, the gold market is subjected to speculation through the use of market instruments such as derivatives. Investors in advanced and emerging markets often switch between oil and gold or combine them to diversify their portfolios (Soytas et al., 2009). Monetary authorities throughout the world pay close attention to gold prices to determine if their monetary policies are on course (Le \& Chang, 2012). The conventional wisdom is that gold has had low correlation with other commodity prices and it is of our interest to prove it.

Silver, on the other hand, is similar to gold in the sense that it also has a long history as currency, reserves and an investment tool. Since the end of the silver standard, however, silver has lost its role as a legal tender in many developed countries. Like gold, silver is traded largely in the LBM but the silver market is smaller than gold.

Agricultural commodity price volatility has been growing concern for many years now. Prior to the global financial crisis, an unprecedented global commodity boom took the world by storm. The boom, also known as the "commodity supercycle", saw the real price of food commodities increased by seventy-five per cent over five years, from 2003 to 2008 (Erten \& Ocampo, 2013). The U.S Drought 2012, which is one of the most severe and extensive drought in 25 years, also had adverse impacts on crop and livestock sectors. The result was higher agricultural prices. All these underlined the needs for policymakers as well as farmers to better understand the volatility of agricultural price in a bid to lower the risks faced by many stakeholders. In 2009, the Organization for Economic Co-operation and Development (OECD) highlighted that the agricultural market remains unprotected to the following risks: institutional, market, financial and personal risks. Out of these risks, market risk remains as one of the most salient as it encompasses a lot of the uncertainties farmers will obtain for their products to pay for their inputs. 


\section{Literature Review}

There is a large amount of literature on the price volatility of individual commodities and associated volatility characteristics. Some non-comparative literature include Narayan and Narayan (2007), Kuper (2002) and Gileva (2010) who have attempted to model oil price volatility using parametric methods such as GARCH and EGARCH. They seem to have come to different conclusions on the asymmetry of effects that shocks have on the volatility of crude oil ranging from a total absence of asymmetry to a clear indication of asymmetry. Other literature focusing on volatility modeling of other commodities such as agricultural commodities have also been done using similar parametric methods and have come to the conclusion that the median volatility of these agricultural commodity groups have not increased nor decreased from 1957-2001 (Moledina, Roe, \& Shane, 2004).

In contrast, comparative studies on volatility modeling are also abundant with a variety of different parametric and non-parametric methods. The non-parametric approach was adopted by Plourde and Watkins (1998), Regnier (2007) and Calvo-Gonzalez, Shankar and Trezzi (2010) where the first two studies concluded that generally crude oil prices were more volatile as compared to a variety of other commodities while Gonzalez, Shankar and Trezzi (2010) argued that there has been no upward or downward trend in volatility over time.

Studies by Narayan and Liu (2011), Clem (1985) and Jacks, O'Rourke and Williamson (2009), however, adopted parametric approaches. The study done by Narayan and Liu (2011) is the closest to ours, as the bundle of commodities being compared contains both gold and silver which are also being studied in this paper. The latter two studies focused on examining the volatility of oil with respect to non-crude oil material.

Additionally, comparative studies on the correlation and causality relationships between commodity prices have also been done using standard methods such as the Johansen cointegration test, VAR and VECM models. For example, Saghaian (2010) evaluated the correlation and causality relationships between crude oil, ethanol and a variety of agricultural commodities using the VECM model, and concluded that although there may be correlation between oil and other commodities, there is mixed evidence of causality between commodities. Another paper by Le and Chang (2011), focusing on the relationship between oil and gold, have instead found a long-run relationship between the two commodities after testing for correlation and causality. Le and Chang (2016) explored dynamics between strategic commodities and found that oil prices seem to not give any information about price fluctuations of financial variables such as interest rate, exchange rate or stock prices in the long run but some information about volatility of those variables in the short run.

Even though studies of energy, metals, agriculture commodities, or a combination of either two groups are aplenty, there seems to be no studies examining these three commodity classes altogether with the application of parametric methods such as GARCH to model volatility.

\section{Data and Methods}

\subsection{Data}

For this study, daily price series of Brent crude oil, gold, silver, wheat, corn and soybean covering the period between 01 January 1986 and 31 December 2010 are employed (Note 4). The data for precious metals of gold and silver reflect LBM prices. The data for wheat, corn and soybean were sourced from the U.S. Department of Agriculture (USDA) while Brent (current month f.o.b.) price series were sourced from Independent Chemical Information Service (ICIS) Pricing. The data on all series are compiled from DataStream. In total, there are 39,138 daily prices (six commodities *6523 daily prices) and the sample period will be divided every five years to form five sub-sample periods: 1986/1990, 1991/1995, 1996/2000, 2001/2005 and 2006/2010.

The return is calculated as the logarithm of price at the present period less the logarithm of price at the last period. Table 1 shows the descriptive statistics for prices and returns of all the six commodities for the whole period of 1986-2010. The Jarque-Bera test statistics suggest that neither prices nor returns are normally distributed. Therefore, when modeling volatility using return series, one could either use a non-normal distribution such as the Student- $t$ distribution (or that with fixed degree of freedom) and the generalized error distribution (or that with fixed parameter), or use robust standard errors by selecting Bollerslev-Wooldridge heteroskedasticity consistent covariance matrix. This paper adopts the second alternative so as to obtain valid inferences. In addition, the kurtosis greater than three implies the series has a fat tail. For the price series, the positive skewness indicates the presence of a right tail; and for the return series, there is evidence of a left tail. The right tail of prices and left tail of returns are also found in Salisu and Fasanya (2013). Furthermore, the standard deviation of return series seems to suggest that Brent is the most volatile among the six. But whether it is always more volatile across the whole time span is worthy of more investigation. 
Table 1. Descriptive statistics for prices and returns

\begin{tabular}{lcccccc}
\hline & Brent & Gold & Silver & Wheat & Soybean & Corn \\
\hline Panel A: Prices & & & & & & \\
\hline Mean & 33.15 & 463.91 & 7.22 & 3.66 & 6.62 & 2.55 \\
Median & 20.80 & 383.40 & 5.31 & 3.45 & 5.89 & 2.33 \\
Maximum & 145.61 & 1417.85 & 30.70 & 11.95 & 16.19 & 7.08 \\
Minimum & 8.75 & 252.85 & 3.55 & 1.92 & 3.88 & 1.22 \\
Std. dev. & 24.65 & 235.04 & 4.34 & 1.21 & 2.03 & 0.87 \\
Skewness & 1.67 & 2.04 & 2.07 & 2.09 & 1.61 & 1.76 \\
Kurtosis & 5.31 & 6.51 & 7.30 & 9.23 & 5.64 & 6.75 \\
Jarque-Bera & 4472 & 7865 & 9714 & 15290 & 4699 & 7192 \\
Observations & 6523 & 6523 & 6523 & 6523 & 6523 & 6523 \\
\hline Panel B: Returns & & & & & 0.03 \\
\hline Mean & 0.0002 & 0.0002 & 0.0003 & 0.0001 & 0.0001 & 0.0001 \\
Median & 0.0000 & 0.0000 & 0.0000 & 0.0000 & 0.0000 & 0.0000 \\
Maximum & 0.1942 & 0.0738 & 0.1828 & 0.2258 & 0.0745 & 0.0947 \\
Minimum & -0.4387 & -0.0722 & -0.1608 & -0.2295 & -0.1673 & -0.1258 \\
Std. dev. & 0.0248 & 0.0096 & 0.0181 & 0.0220 & 0.0152 & 0.0182 \\
Skewness & -0.8915 & -0.1728 & -0.1940 & -0.4863 & -0.7669 & -0.3749 \\
Kurtosis & 25.1075 & 10.2134 & 10.9787 & 15.0404 & 10.0986 & 7.7621 \\
Jarque-Bera & 133680 & 14172 & 17341 & 39653 & 14333 & 6315 \\
Observations & 6522 & 6522 & 6522 & 6522 & 6522 & 6522 \\
\hline & & & & &
\end{tabular}

The dynamics of prices and returns of Brent oil, Gold, Silver, Wheat, Soybean and Corn is plotted in Figure 1. It is obvious that (1) the volatility of the series is not constant over time; (2) return series show evidence of volatility clustering in the sense that periods of high returns are followed by periods of high returns, and periods of small returns are followed by periods of small returns; (3) some of the series seem to exhibit breaks, particularly around the time the financial crisis to be broke out (Note 5).

Table 2 shows the unit root test results for the returns both in the whole sample and in five sub-sample periods. The augmented Dickey-Fuller, or ADF (Dickey and Fuller, 1981) test is employed on the return series with intercept only. The results show that the null hypothesis of existence of a unit root is significantly rejected at the conventional levels of significance, suggesting stationarity of return series. The stationarity of returns are also supported by other unit root tests such as Phillips-Perron (PP) test (Phillips \& Perron, 1988) and Kwiatkowski-Philips-Schmidt-Shin (KPSS) test (Kwiatkowski et al., 1992). Furthermore, ARCH test statistics reject the "no ARCH" hypothesis for all the six return series (Note 6). Due to space limitation, these results are not reported but available from authors upon request. Based on the above pre-estimation analysis, it is appropriate to model the volatility via GARCH models.
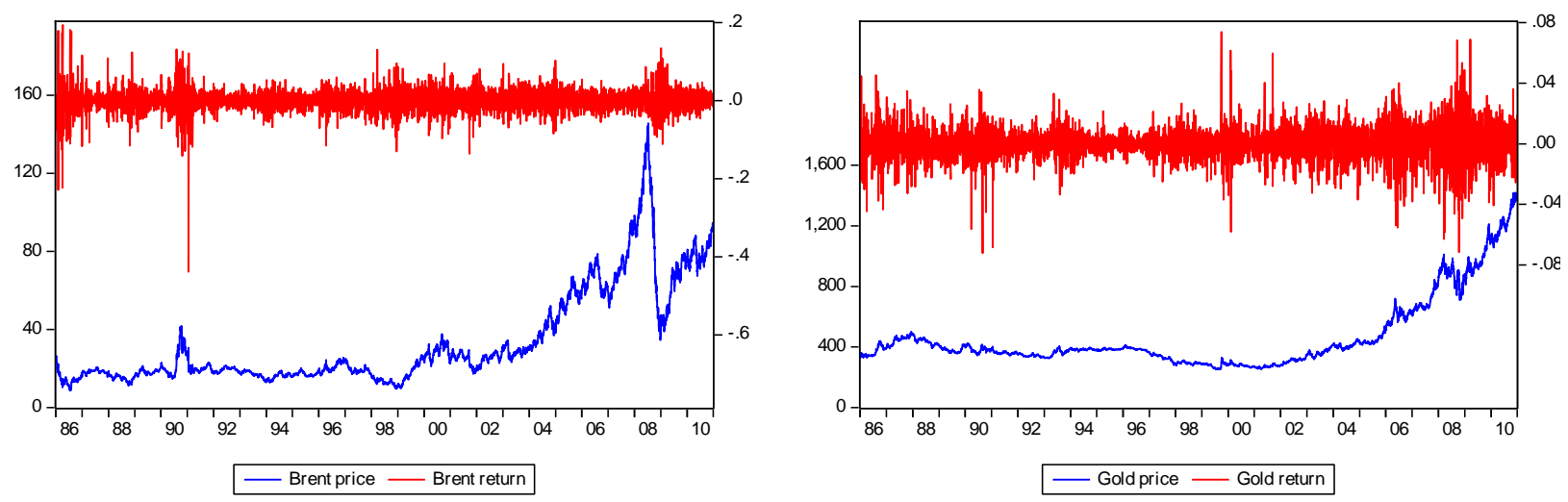

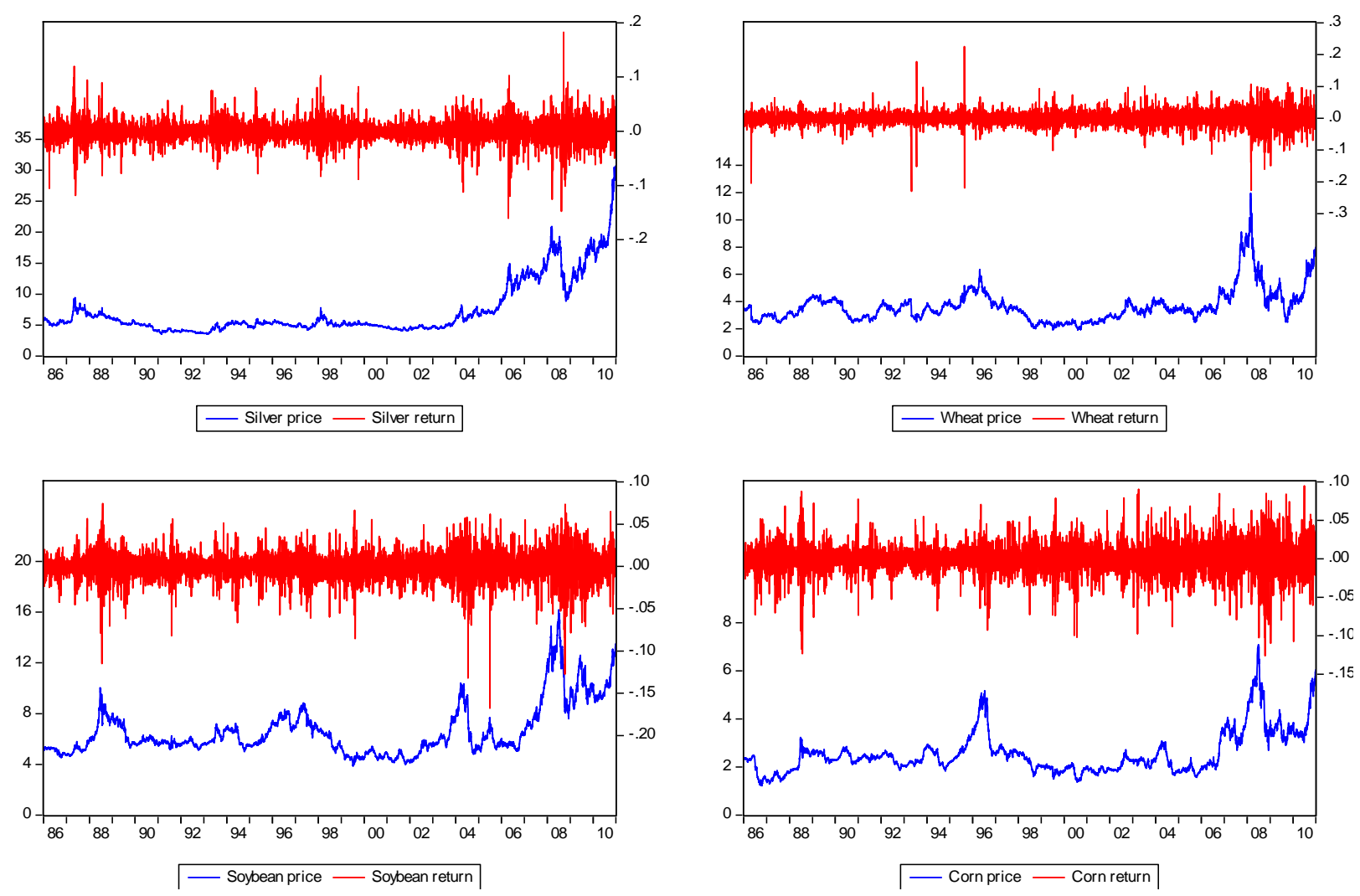

Figure 1. Plots of prices and returns for the period 1986-2010

Table 2. ADF-unit root test results for the returns

\begin{tabular}{lllllll}
\hline & Brent & Gold & Silver & Wheat & Soybean & Corn \\
\hline Full sample & -81.505 & -81.552 & -88.687 & -86.452 & -83.132 & -80.334 \\
$1986-1990$ & -37.294 & -37.826 & -41.737 & -38.059 & -37.743 & -35.327 \\
$1991-1995$ & -25.194 & -37.233 & -39.789 & -38.839 & -37.396 & -37.505 \\
$1996-2000$ & -36.144 & -34.447 & -42.465 & -35.262 & -35.881 & -34.801 \\
$2001-2005$ & -38.073 & -36.424 & -37.195 & -38.371 & -38.376 & -37.606 \\
$2006-2010$ & -35.478 & -36.428 & -38.573 & -40.038 & -36.495 & -35.680 \\
\hline
\end{tabular}

Note. The test is based on the level data with only intercepts and no time trends in the model. In the table are t-statistics of ADF-unit root test. As shown, all statistics are rejected at the $1 \%$ significance level, indicating no unit root in the return series.

\subsection{Econometric models}

\subsubsection{Modeling Volatility}

GARCH models (Engle, 1982; Bollerslev, 1986) are employed when the error term shows conditional heteroskedasticity. Let the error process be such that

$$
\varepsilon_{t}=v_{t} \sqrt{h_{t}},
$$

where $\left\{v_{t}\right\}$ is a white-noise process with $\sigma_{v}^{2}=1$ and

$$
h_{t}=a_{0}+\sum_{i=1}^{q} a_{i} \varepsilon_{t-i}^{2}+\sum_{j=1}^{p} b_{j} h_{t-j},
$$

The conditional variance of $\varepsilon_{t}$ is given by $E_{t-1} \varepsilon_{t}^{2}=h_{t}$, which is an ARMA process. This is known as the generalized $A R C H$ or $\operatorname{GARCH}(p, q)$ model. Usually it is adequate to obtain a good model fit for stationary financial time series with ARCH effects using a $\operatorname{GARCH}(1,1)$ model with only three parameters in the conditional variance equation. Indeed, Hanes and Lunde (2004) provided compelling evidence that it is difficult to find a volatility model that outperforms the simple $\operatorname{GARCH}(1,1)$.

The GARCH $(1,1)$ shows mean reversion to a constant for all time. When the mean reverts to a varying level, the 
Component GARCH $(C G A R C H)$ is appropriate. The $\operatorname{CGARCH}(1,1)$ model is as follows:

$$
\begin{gathered}
h_{t}-m_{t}=a_{1}\left(\varepsilon_{t-1}^{2}-m_{t-1}\right)+b_{1}\left(h_{t-1}-m_{t-1}\right), \\
m_{t}=c+\rho\left(m_{t-1}-c\right)+\phi\left(\varepsilon_{t-1}^{2}-h_{t-1}\right),
\end{gathered}
$$

Where $m_{t}$ is the time varying long-run volatility. Equations (3) and (4) describe transitory and permanent components, respectively. The transitory component, $h_{t}-m_{t}$, converges to zero with powers of $a_{1}+b_{1}$, while the permanent component $m_{t}$ converges very slowly to $c$ with powers of $\rho$, which is typically near to 1 .

Both GARCH and CGARCH are used to account for symmetric volatility effects. It is widely known, however, that empirically bad news (negative shocks) or good news (positive shocks) induce asymmetric or leverage effects on the conditional volatility of most financial assets. Consequently, the $\operatorname{GARCH}(1,1)$ and $\operatorname{CGARCH}(1,1)$ models would not be suitable and we will next consider two different asymmetric volatility models when there are the leverage effects.

The first one is the exponential GARCH (EGARCH) model proposed by Nelson (1991). The EGARCH(1,1) is specified as follows:

$$
\ln \left(h_{t}\right)=a_{0}+a_{1} \frac{\left|\varepsilon_{t-i}\right|}{\sqrt{h_{t-i}}}+\lambda_{1} \frac{\varepsilon_{t-1}}{\sqrt{h_{t-1}}}+b_{1} \ln \left(h_{t-1}\right)
$$

Note that when $\varepsilon_{t-1}$ is positive or there is "good news", the effect of standardized value of $\varepsilon_{t-1}\left(i . e ., \frac{\varepsilon_{t-1}}{\sqrt{h_{t-1}}}\right)$ on the $\log$ of the conditional variance is $\left(a_{1}+\lambda_{1}\right)$; in contrast, when $\varepsilon_{t-1}$ is negative or there is "bad news", the effect of standardized value of $\varepsilon_{t-1}$ is $\left(a_{1}-\lambda_{1}\right)$. Bad news can have a larger impact on volatility when the value of $\lambda_{1}$ is negative. An advantage of the EGARCH model over the basic GARCH model is that the conditional variance $h_{t}$ is guaranteed to be positive regardless of the values of the coefficients in (5), because the logarithm of $h_{t}$ instead of $h_{t}$ itself is modeled.

The second GARCHvariant that is capable of modeling leverage effects is the threshold GARCH (TGARCH) model proposed by Glosten, Jagannathan, Runkle (1994) (Note 7). The $\operatorname{TGARCH}(1,1)$ has the following form

$$
h_{t}=a_{0}+a_{1} \varepsilon_{t-1}^{2}+\lambda_{1} S_{t-1} \varepsilon_{t-1}^{2}+b_{1} h_{t-1}
$$

where

$$
S_{t-1}= \begin{cases}1 & \text { if } \varepsilon_{t-1}<0 \\ 0 & \text { if } \varepsilon_{t-1} \geq 0\end{cases}
$$

That is, depending on whether $\varepsilon_{t-1}$ is above or below the threshold value of zero, an $\varepsilon_{t-1}$ shock has different effects on the conditional variance $h_{t}$. When $\varepsilon_{t-1}$ is positive, the total effects are given by $a_{1} \varepsilon_{t-1}^{2}$; when $\varepsilon_{t-1}$ is negative, the total effects are given by $\left(a_{1}+\lambda_{1}\right) \varepsilon_{t-1}^{2}$. Therefore, one would expect $\lambda_{1}$ to be positive for bad news having larger impacts.

To clearly see the leverage effects in these models, Pagan and Schwert (1990) and Engle and Ng (1993) advocated the use of news impact curve. They defined the news impact curve as the functional relationship between conditional variance at time tand the shock term (error term) at time $t-1$, holding constant the information dated $\mathrm{t}-2$ and earlier, and with all lagged conditional variance evaluated at the level of the unconditional variance. Therefore, the equation for the $\operatorname{EGARCH}(1,1)$ news impact curve is:

$$
h_{t}=A \exp \left\{\left(a_{1}\left|\varepsilon_{t-1}\right|+\lambda_{1} \varepsilon_{t-1}\right) / \bar{\sigma}\right\},
$$

where $A=\bar{\sigma}^{2 b_{1}} \exp \left\{a_{0}\right\}$, and $\bar{\sigma}^{2}=\exp \left\{\left(a_{0}+a_{1} \sqrt{2 / \pi}\right) /\left(1-b_{1}\right)\right\}$

The equation for the $\operatorname{TGARCH}(1,1)$ news impact curve is:

$$
h_{t}=A+\left(a_{1}+\lambda_{1} S_{t-1}\right) \varepsilon_{t-1}^{2}
$$

where $A=a_{0}+b_{1} \bar{\sigma}^{2}$, and $\bar{\sigma}^{2}=a_{0} /\left[1-\left(a_{1}+\frac{\lambda_{1}}{2}\right)-b_{1}\right]$.

\subsubsection{Engle-Granger Two-Step Error Correction Model}

To examine the cointegration and causality between two variables, we adopt the Engle-Granger two-step error correction model. The first step is to conduct the Engle-Granger cointegration test, which is preferable to Johansen cointegration test (Johansen \& Juselius, 1990) because we are only interested in the bivariate relationship instead of cointegration within a multivariate framework. Both variables have to be integrated of the 
same order before checking for any possible cointegration. When both variables are integrated of the same order, say $I(1)$, using methods suggested by Engle and Granger (1987), one can first regress one $I(1)$ variable on another using ordinary least squares:

$$
Y_{t}=\alpha+\beta Z_{t}+\varepsilon_{t}
$$

The estimated residuals are then tested for non-stationarity using the ADF and PP tests using optimal lags suggested by Akaike information criterion (AIC) and Schwarz information criterion (SIC) tests. The null hypothesis is that the residuals are non-stationary and rejection of the null hypothesis leads to the conclusion that the residuals are stationary and the series are cointegrated. If the two non-stationary time series variables are cointegrated and have a long-run relationship, they are expected to move together through time. However, if the variables are integrated of different orders, it can be concluded that they are not cointegrated.

A conintegrating relationship implies the existence of causality in at least one direction. Upon establishing a cointegrating relationship and obtaining an estimate of residuals, the second step is to identify the direction of Granger causality through an Error Correction Model (ECM). All the variables in this model have to be stationary. The basic structure of the ECM is as follows:

$$
\begin{aligned}
& \Delta Y_{t}=\alpha_{1}+\beta_{1} E C_{t-1}+\sum_{i=1} a_{11}(i) \Delta Y_{t-i}+\sum_{i=1} a_{12}(i) \Delta Z_{t-i}+\varepsilon_{y t} \\
& \Delta Z_{t}=\alpha_{2}+\beta_{2} E C_{t-1}+\sum_{i=1} a_{21}(i) \Delta Y_{t-i}+\sum_{i=1} a_{22}(i) \Delta Z_{t-i}+\varepsilon_{z t}
\end{aligned}
$$

The EC component is derived from the cointegrated time series $E C_{t}=Y_{t}-\left(\alpha+\beta X_{t}\right)$. The coefficient $\beta_{1}$ captures the rate at which $Y$ adjusts to the deviation from long-run equilibrium in the last period, and the coefficient $\beta_{2}$ captures the adjustment speed of the variable $Z$ to its long-run equilibrium. Direct convergence necessitates that $\beta_{1}$ be negative and $\beta_{2}$ be positive. If $\beta_{1}=0$ and $a_{12}(i)=0$, it can be said that the variable $Z$ does not Granger cause $Y$ in the long run. Similarly, if $\beta_{2}=0$ and $a_{21}(i)=0, Y$ does not Granger cause $Z$ in the long run.

\section{Results and Discussion}

\subsection{Do Price Shocks have Asymmetric Effects on Volatility?}

The volatility modelling procedures are summarized below:

Step 1: Analyze time series plot and descriptive statistics

Step 2: Generate stationary data by first differencing

Step 3: Return series and its ACF plots are checked for further confirmation of stationarity

Step 4: Since squared returns measure the second order moment of the commodity's time series, its ACF is plotted to check for autocorrelation.

Step 5: Ljung-Box and ARCH LM tests with 5\% significance level with 10, 20 and 30 lags are conducted as further confirmation. If autocorrelation and $\mathrm{ARCH}$ effects are rejected, time series do not exhibit time varying conditional heteroskedasticity or volatility clustering; otherwise, time series exhibits time varying conditional heteroskedasticity or volatility clustering.

Step 6: Return series is modelled using $\operatorname{GARCH}(1,1)$. Use AIC and SIC to select the best model across 5 different conditional densities for the innovations (i.e. Normal, Student's t, Generalized Error Distribution (GED), Student's t with fixed degrees of freedom, and GED with fixed parameter); or, use robust standard errors (Bollerslev-Wooldridge covariance matrix) for normal distribution.

Step 7: Conduct Sign Bias test (SB test) to determine if the time series exhibits symmetric volatility effects. If the null hypothesis is rejected, model the volatility based on the 3 models $(\operatorname{EGARCH}(1,1)$, GJR-GARCH$(1,1)$ and APARCH $(1,1,1)$ ); and the final model is chosen based on BIC followed by model checks on the standardized residuals to assess its suitability. If one fails to reject the null hypothesis, further model checks using Ljung-Box and ARCH LM tests on the standardized residuals and Q-Q plot are utilized to assess model's suitability

Step 8: Indicate the persistence and leverage effect respectively. News impact curves is plotted to demonstrate the effects of good and bad news have on the conditional volatility of the commodity.

Following the procedures, we choose the model specifications for the returns of each commodity for each sub-sample period. The model and corresponding estimation results for the variance equation are listed in Table 3. 
Table 3. Estimation results for the variance equation

\begin{tabular}{|c|c|c|c|c|c|c|}
\hline & Brent & Gold & Silver & Wheat & Soybean & Corn \\
\hline \multicolumn{7}{|c|}{$1986 / 1990$} \\
\hline Model & $\operatorname{GARCH}(1,1)$ & $\operatorname{TGARCH}(1,1)$ & TGARCH $(1,1)$ & $\operatorname{GARCH}(1,1)$ & $\operatorname{EGARCH}(1,1)$ & $\operatorname{GARCH}(1,1)$ \\
\hline$a_{0}$ & $2.72 \mathrm{E}-05^{* * *} *$ & 0.15 E-05 & $1.10 \mathrm{E}-05^{* *}$ & $5.65 \mathrm{E}-05^{* * *}$ & $-0.2306 * * *$ & 1.04 E-05*** \\
\hline$a_{1}$ & $0.2468^{* * *}$ & $0.0473^{* *}$ & $0.1302 * * *$ & $0.1929 *$ & $0.1764^{* * *}$ & $0.1407^{* * *}$ \\
\hline$b_{1}$ & $0.7472^{* * *}$ & $0.9650^{* * *}$ & $0.8875^{* * *}$ & $0.5865 * * *$ & $0.9889^{* * *}$ & $0.8254 * * *$ \\
\hline$\lambda_{1}$ & & $-0.0561 * *$ & $-0.1111 * * *$ & & $0.0548 * * *$ & \\
\hline \multicolumn{7}{|c|}{ Diagnostics } \\
\hline AIC & -4.7126 & -6.5455 & -5.5248 & -5.5537 & -6.0513 & -5.5770 \\
\hline SIC & -4.6887 & -6.5217 & -5.5010 & -5.5339 & -6.0275 & -5.5571 \\
\hline \multicolumn{7}{|c|}{ ARCH LM test } \\
\hline F-test & 0.3312 & 0.848 & 0.7386 & 0.2038 & 0.2619 & 0.1896 \\
\hline $\mathrm{n} R^{2}$ & 0.3316 & 0.8488 & 0.7393 & 0.204 & 0.2622 & 0.1899 \\
\hline \multicolumn{7}{|c|}{ 1991/1995 } \\
\hline Model & $\operatorname{GARCH}(1,1)$ & EGARCH $(1,1)$ & $\operatorname{TGARCH}(1,1)$ & $\operatorname{TGARCH}(1,1)$ & $\operatorname{TGARCH}(1,1)$ & $\operatorname{GARCH}(1,1)$ \\
\hline$a_{0}$ & 0.42 E- $05 * *$ & $-0.0919 * *$ & 0.33 E- $05 * *$ & 1.04 E-05 & $0.26 \mathrm{E}-05^{* *}$ & $0.55 \mathrm{E}-05^{* * *}$ \\
\hline$a_{1}$ & $0.0434 * * *$ & $0.0654 * * *$ & $0.0925^{* * *}$ & 0.0587 & $0.1124 * * *$ & $0.0866^{* * *}$ \\
\hline$b_{1}$ & $0.9368^{* * *}$ & $0.9957 * * *$ & $0.9238^{* * *}$ & $0.8530 * * *$ & $0.9165^{* * *}$ & $0.8727 * * *$ \\
\hline$\lambda_{1}$ & & $0.0625^{* * *}$ & $-0.0609^{*}$ & $0.1935 \mathrm{a}$ & $-0.0909 * * *$ & \\
\hline \multicolumn{7}{|c|}{ Diagnostics } \\
\hline AIC & -5.4198 & -7.5604 & -5.6946 & -5.3156 & -6.285 & -6.1641 \\
\hline SIC & -5.4 & -7.5366 & -5.6708 & -5.2918 & -6.2612 & -6.1442 \\
\hline \multicolumn{7}{|c|}{ ARCH LM test } \\
\hline F-test & 0.8817 & 0.13764 & 0.1578 & 1.9827 & 0.2808 & $2.8794 *$ \\
\hline $\mathrm{n} R^{2}$ & 0.8825 & 0.1378 & 0.158 & 1.9827 & 0.2812 & $2.8774^{*}$ \\
\hline \multicolumn{7}{|c|}{ 1996/2000 } \\
\hline Model & $\operatorname{GARCH}(1,1)$ & CGARCH $(1,1)$ & CGARCH $(1,1)$ & $\operatorname{GARCH}(1,1)$ & $\operatorname{GARCH}(1,1)$ & $\operatorname{GARCH}(1,1)$ \\
\hline$a_{0}$ & $3.21 \mathrm{E}-05^{*}$ & - & - & $1.17 \mathrm{E}-05^{*}$ & $0.72 \mathrm{E}-05^{* *}$ & $0.67 \mathrm{E}-05^{* * *}$ \\
\hline$a_{1}$ & $0.0596^{* *}$ & $0.1383^{* *}$ & $0.1230 * *$ & $0.0551 * *$ & $0.0844^{* * *}$ & $0.0830^{* * *}$ \\
\hline$b_{1}$ & $0.8886^{* * *}$ & $0.6305^{* * *}$ & 0.3185 & $0.9097 * * *$ & $0.8788^{* * *}$ & $0.8983^{* * *}$ \\
\hline \multicolumn{7}{|l|}{$\lambda_{1}$} \\
\hline \multicolumn{7}{|c|}{ Diagnostics } \\
\hline AIC & -4.6079 & -7.273 & -5.7695 & -5.2321 & -5.8302 & -5.3495 \\
\hline SIC & -4.588 & -7.2452 & -5.7417 & -5.2123 & -5.8104 & -5.3297 \\
\hline \multicolumn{7}{|c|}{ ARCH LM test } \\
\hline F-test & 0.1086 & 2.3569 & 0.2964 & 1.5417 & 0.0321 & 0.3352 \\
\hline $\mathrm{n} R^{2}$ & 0.1088 & 2.3562 & 0.2968 & 1.5422 & 0.0321 & 0.3357 \\
\hline \multicolumn{7}{|c|}{ 2001/2005 } \\
\hline Model & $\operatorname{TGARCH}(1,1)$ & EGARCH $(1,1)$ & $\operatorname{TGARCH}(1,1)$ & $\operatorname{TGARCH}(1,1)$ & $\operatorname{TGARCH}(1,1)$ & $\operatorname{GARCH}(1,1)$ \\
\hline$a_{0}$ & $3.61 \mathrm{E}-05^{* *}$ & $-0.3041 *$ & 0.08 E-05 & $0.81 \mathrm{E}-05^{* *}$ & $-0.0969 * *$ & $1.23 \mathrm{E}-05$ \\
\hline$a_{1}$ & 0.0334 & 0.0382 & $0.0579 * * *$ & 0.0096 & $0.1040 * * *$ & $0.0506^{* * *}$ \\
\hline$b_{1}$ & $0.8603^{* * *}$ & $0.9709 * * *$ & $0.9664 * * *$ & $0.9487 * * *$ & $0.9975^{* * *}$ & $0.9085^{* * *}$ \\
\hline$\lambda_{1}$ & $0.0661^{*}$ & $0.0607 * * *$ & $-0.0502 * * *$ & $0.0483 * *$ & $0.0384 \mathrm{a}$ & \\
\hline \multicolumn{7}{|c|}{ Diagnostics } \\
\hline AIC & -4.7945 & -6.6902 & -5.7051 & -5.0001 & -5.503 & -5.3352 \\
\hline SIC & -4.7708 & -6.6664 & -5.6813 & -4.9763 & -5.4792 & -5.3154 \\
\hline \multicolumn{7}{|c|}{ ARCH LM test } \\
\hline F-test & 0.9645 & 2.3716 & $7.9532 * * *$ & 0.057 & 0.9168 & 2.6298 \\
\hline $\mathrm{n} R^{2}$ & 0.9653 & 2.3709 & $7.9170 * * *$ & 0.0571 & 0.9176 & 2.6285 \\
\hline \multicolumn{7}{|c|}{$2006 / 2010$} \\
\hline Model & $\operatorname{TGARCH}(1,1)$ & TGARCH $(1,1)$ & $\operatorname{GARCH}(1,1)$ & $\operatorname{GARCH}(1,1)$ & $\operatorname{GARCH}(1,1)$ & $\operatorname{EGARCH}(1,1)$ \\
\hline$a_{0}$ & $0.26 \mathrm{E}-05$ & 0.09 E-05 & $1.21 \mathrm{E}-05^{*}$ & $1.74 \mathrm{E}-05^{* *}$ & $0.42 \mathrm{E}-05^{* *}$ & $-0.1715^{*}$ \\
\hline$a_{1}$ & 0.0014 & $0.0672 * * *$ & $0.0681 * *$ & $0.0673 * * *$ & $0.0537 * * *$ & $0.0696^{* *}$ \\
\hline$b_{1}$ & $0.9579 * * *$ & $0.9544 * * *$ & $0.9142 * * *$ & $0.9163 * * *$ & $0.9337 * * *$ & $0.9841 * * *$ \\
\hline$\lambda_{1}$ & $0.0675^{* * * *}$ & $-0.0463 * *$ & & & & $-0.0293 *$ \\
\hline
\end{tabular}




\begin{tabular}{|c|c|c|c|c|c|c|}
\hline \multicolumn{7}{|c|}{ Diagnostics } \\
\hline AIC & -4.9874 & -5.8624 & -4.6957 & -4.1926 & -5.3086 & -4.6944 \\
\hline SIC & -4.9636 & -5.8386 & -4.6758 & -4.1728 & -5.2888 & -4.6706 \\
\hline \multicolumn{7}{|c|}{ ARCH LM test } \\
\hline F-test & 0.9489 & 1.4106 & 0.2766 & 0.4415 & 0.1042 & 1.1026 \\
\hline $\mathrm{n} R^{2}$ & 0.9497 & 1.4112 & 0.277 & 0.442 & 0.1043 & 1.1033 \\
\hline
\end{tabular}

In the GARCH(1,1) models for Brent and Corn for the periods 1986-1990, 1991-1995, and 1996-2000, for Wheat and Soybean during 1996-2000 and 2006-2010, for Corn during 2001-2005, and for Silver during 2006-2010, the sum of $A R C H$ and GARCH effects is close to one, indicating shocks to volatility have a persistent effect on the conditional variance (Note 8). While volatility of Wheat for the period of 1986-1990 follows $\operatorname{GARCH}(1,1)$, the reversion to the mean is much quicker than other variance processes (the sum of ARCH and GARCH effects is 0.78 , much less than 1). Volatility of Gold and Silver for the period of 1996-2000 seems to be best fitted by $\operatorname{CGARCH}(1,1)$, which allows for mean reversion to a time varying long-run volatility. The estimation for the long run component reveals that the time varying long-run volatility reverts very slowly (the coefficient estimate is between 0.99 and 1). On the other hand, the transitory component shows that it converges to zero with powers of 0.77 and 0.44 respectively (as indicated by $0.63+0.14$ and $0.12+0.32$ ).In sum, price shocks have symmetric effect on the volatility of these markets.

For the rest, the volatility is best modeled using asymmetric GARCH models. The results of TGARCH and EGARCH models show evidence of leverage effects (as indicated by estimates of $\lambda_{1}$ ) and therefore they are chosen over the symmetric models. We anticipate that bad news (negative shocks) has the tendency to cause a larger impact on volatility in most financial assets than good news (positive shocks) do. In the TGARCH models, the coefficient measuring the leverage effect is positive for Wheat during 1991-1995, for Brent, Wheat and Soybean during 2001-2005, and for Brent during 2006-2010, indicating that bad news have a larger impact on price volatility than good news in these markets, while the coefficient is negative for Gold and Silver for the periods 1986-1990, Silver and Soybean for 1991-1995, Silver for 2001-2005and Gold for 2006-2010, suggesting that good news have a larger impact for markets at the specific time period. In the EGARCH models, a positive coefficient of $\lambda_{1}$ indicates good shocks affecting volatility more than bad shocks, and vice versa. As such, the market of Soybean in late 1980s, Gold in the first half of 1990s and 2000s are found to be affected more by positive shocks than negative shocks, while in the Corn market for 2006-2010, bad news has a larger impact on the volatility.

Next to the estimation results, the diagnostic statistics of AIC and SIC, which are used for the selection of volatility model specifications are reported. The post-estimation $A R C H$ tests (both the $F$-test and Chi-square distributed $n R^{2}$ test) are carried out to ensure $A R C H$ effects in the return series are well captured by the GARCH model. As results show, the null hypothesis of "no $A R C H$ effect" could not be rejected at the conventional levels of significance.

Returns' volatility implied by the family of GARCH models has important implications for portfolio selection and asset pricing. They serve as an important input to determine value of options and as volatility estimates for dynamic hedging strategies. These concerns point to the need to have a correct understanding of the impact of news on volatility. As discussed in the above section, we will use the news impact curve following Engle and $\mathrm{Ng}$ (1993) who defined the news impact curve as follows:

The news impact curve is the functional relationship between conditional variance at time $t$ and the shock term (error term) at time $t-1$, holding constant the information dated $t-2$ and earlier, and with all lagged conditional variance evaluated at the level of the unconditional variance.

Based on the model estimations in Table 3, we obtain the results of the presence and magnitude of the asymmetric effects as summarized in Table 4 . It is observed that the price volatility of Corn is quite symmetric in early days, and it is not until the most recent five-year period (i.e., 2001-2005) it began to show asymmetric volatility. Brent's volatility also became more asymmetric, while Gold price has shown asymmetric volatility most of the time. Commodities' volatility and its implications deserve a study here as asymmetries in commodities' volatility would inevitably affect the exchange rate and aggregate demand of an economy. It will also have an impact on the commodities' investments of market participants. Wild price swings can cause huge 
monetary losses if trades are left un-hedged or investments are made based on poor and complacent risk management systems. The findings on price volatility and asymmetric effects are thus of much interest to both traders and investors.

Table 4. News impact on commodities

\begin{tabular}{|c|c|}
\hline \multicolumn{2}{|l|}{ 1986-1990 } \\
\hline Brent & Positive and negative shocks induce volatility to change symmetrically in size and direction. \\
\hline Gold & Positive shocks induce $\left(0.0561 \varepsilon_{t-1}^{2}\right)$ more volatility than negative shocks. \\
\hline Silver & Positive shocks induce $\left(0.1111 \varepsilon_{t-1}^{2}\right)$ more volatility than negative shocks. \\
\hline Wheat & Positive and negative shocks induce volatility to change symmetrically in size and direction. \\
\hline Soybean & Positive shocks induce $\left[1.1158 \exp \left(\frac{\left|\varepsilon_{t-1}\right|}{\tau}\right)\right]$ times volatility as do negative shocks. \\
\hline Corn & Positive and negative shocks induce volatility to change symmetrically in size and direction. \\
\hline \multicolumn{2}{|c|}{ 1991-1995 } \\
\hline Brent & Positive and negative shocks induce volatility to change symmetrically in size and direction. \\
\hline Gold & Positive shocks induce $\left[1.1331 \exp \left(\frac{\left|\varepsilon_{t-1}\right|}{\tau}\right)\right]$ times volatility as do negative shocks. \\
\hline Silver & Positive shocks induce $\left(0.0609 \varepsilon_{t-1}^{2}\right)$ more volatility than negative shocks. \\
\hline Wheat & Negative shocks induce $\left(0.1935 \varepsilon_{t-1}^{2}\right)$ more volatility than positive shocks. \\
\hline Soybean & Positive shocks induce $\left(0.0909 \varepsilon_{t-1}^{2}\right)$ more volatility than negative shocks. \\
\hline Corn & Positive and negative shocks induce volatility to change symmetrically in size and direction. \\
\hline \multicolumn{2}{|c|}{ 1996-2000 } \\
\hline Brent & Positive and negative shocks induce volatility to change symmetrically in size and direction. \\
\hline Gold & Positive and negative shocks induce volatility to change symmetrically in size and direction. \\
\hline Silver & Positive and negative shocks induce volatility to change symmetrically in size and direction. \\
\hline Wheat & Positive and negative shocks induce volatility to change symmetrically in size and direction. \\
\hline Soybean & Positive and negative shocks induce volatility to change symmetrically in size and direction. \\
\hline Corn & Positive and negative shocks induce volatility to change symmetrically in size and direction. \\
\hline \multicolumn{2}{|c|}{ 2001-2005 } \\
\hline Brent & Negative shocks induce $\left(0.0661 \varepsilon_{t-1}^{2}\right)$ more volatility than positive shocks. \\
\hline Gold & Positive shocks induce $\left[1.1291 \exp \left(\frac{\left|\varepsilon_{t-1}\right|}{\tau}\right)\right]$ times volatility as do negative shocks. \\
\hline Silver & Positive shocks induce $\left(0.0502 \varepsilon_{t-1}^{2}\right)$ more volatility than negative shocks. \\
\hline Wheat & Negative shocks induce $\left(0.0483 \varepsilon_{t-1}^{2}\right)$ more volatility than positive shocks. \\
\hline Soybean & Negative shocks induce $\left(0.0384 \varepsilon_{t-1}^{2}\right)$ more volatility than positive shocks. \\
\hline Corn & Positive and negative shocks induce volatility to change symmetrically in size and direction. \\
\hline \multicolumn{2}{|c|}{ 2006-2010 } \\
\hline Brent & Negative shocks induce $\left(0.0675 \varepsilon_{t-1}^{2}\right)$ more volatility than positive shocks. \\
\hline Gold & Positive shocks induce $\left(0.0463 \varepsilon_{t-1}^{2}\right)$ more volatility than negative shocks. \\
\hline Silver & Positive and negative shocks induce volatility to change symmetrically in size and direction. \\
\hline Wheat & Positive and negative shocks induce volatility to change symmetrically in size and direction. \\
\hline Soybean & Positive and negative shocks induce volatility to change symmetrically in size and direction. \\
\hline Corn & Negative shocks induce $\left[1.0604 \exp \left(\frac{\left|\varepsilon_{t-1}\right|}{\sigma}\right)\right]$ times volatility as dopositive shocks. \\
\hline
\end{tabular}

Note. For the TGARCH model, the volatility difference induced by positive shocks and negative shocks is $h_{t}^{+}-h_{t}^{-}=-\lambda_{1} \varepsilon_{t-1}^{2}$. For the EGARCH model, the volatility difference induced by positive shocks and negative shocks is $\frac{h_{t}^{+}}{h_{t}^{-}}=e^{2 \lambda_{1}} \exp \left(\frac{\left|\varepsilon_{t-1}\right|}{\sigma}\right)$.

\subsection{Is Brent Always More Volatile across the Period of Testing?}

Given the rising importance of commodities as consumption goods, factors of production and financial assets, it helps to provide more information about the risk and uncertainty behind their price fluctuations for hedgers and investors to better manage their risk limits and prevent huge monetary drawdowns. The question of whether Brent is more volatile than Gold, Silver, Wheat, Soybean and Corn is of interest as the findings may conclude that Brent can be appropriately used as a benchmark for forecasting unrealized volatility.

In order to establish a basis to see which commodity is the most and least volatile per sub-sample, we have chosen to use the means of conditional volatilities. If the mean of Brent's conditional volatility is higher than that of other commodities, we conclude that on average, the frequency of Brent being in a high volatility environment is higher over a similar time period than the compared commodity. As the means of conditional volatility in 
Table 5 results show, over the five sub-samples, Brent is the most volatile commodity only in three periods $1986 / 1990,1996 / 2000$ and 2001/2005. For the other two periods of 1991/1995 and 2006/2010, wheat is the most volatile among the six strategic commodities. Meanwhile, it is interesting to note that gold is the least volatile commodity for all the time. The comparison results of conditional volatility could be seen more straightforwardly in Figure 2, where the scale of the y-axis is set the same. The findings do not provide evidence to the proposition that Brent is more volatile than the five other strategic commodities in all sub-samples.

Table 5. Mean value of conditional volatility

\begin{tabular}{lcccccc}
\hline Time Period & Brent & Gold & Silver & Wheat & Soybean & Corn \\
\hline $1986-1990$ & 0.001160 & 0.000089 & 0.000294 & 0.000260 & 0.000197 & 0.000314 \\
$1991-1995$ & 0.000418 & 0.000036 & 0.000240 & 0.000466 & 0.000130 & 0.000150 \\
$1996-2000$ & 0.000607 & 0.000058 & 0.000242 & 0.000329 & 0.000191 & 0.000328 \\
$2001-2005$ & 0.000512 & 0.000074 & 0.000252 & 0.000416 & 0.000280 & 0.000297 \\
$2006-2010$ & 0.000504 & 0.000202 & 0.000623 & 0.001027 & 0.000342 & 0.000576 \\
\hline
\end{tabular}
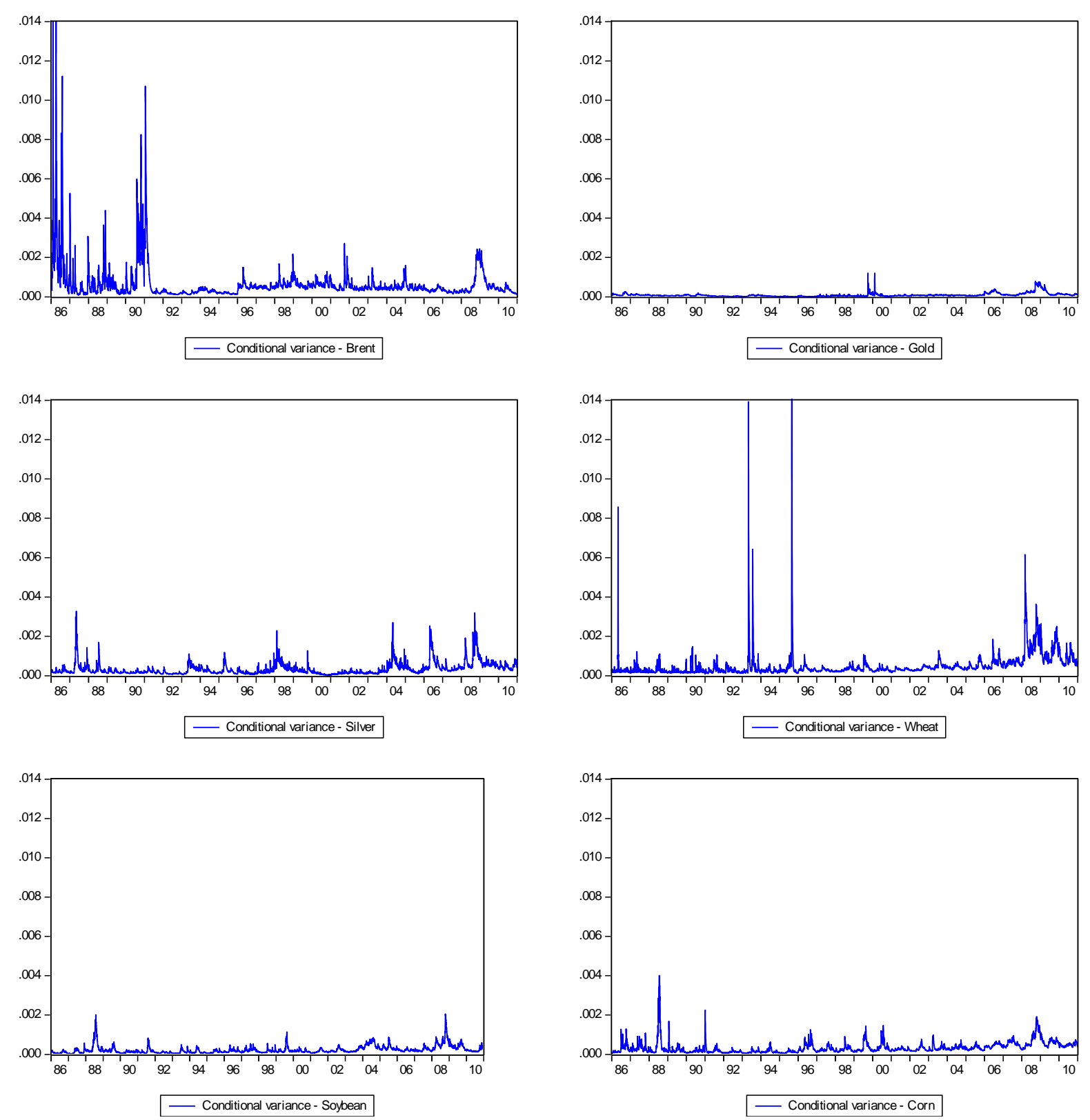

Figure 2. Conditional volatility 


\subsection{Is There Correlation or Causality Between the Commodities?}

Based on the results of the correlation matrices among the six commodities' returns shown in Table A1, it is found that across the 25 years, four pairs of commodities exhibited consistent high positive correlations. They are gold and silver, wheat and corn, soybean and corn, and wheat and soybean. A noteworthy point from this result was that in the last sub-sample period, correlation coefficients among all commodities exhibit strong positive correlations and they have increased significantly compared to other periods. This could be due to the incumbent highly integrated markets where hedge funds and traders trade all the commodities in the same basket. Erten and Ocampo (2013) attributed the upswing in agricultural commodity prices during the commodity super-cycle period to "extraordinary resilience of growth performance of major developing country demanders of commodities, particularly China". While many parties pushed the blame entirely to China's new consumption pattern, there are also others who blamed it on other factors such as the weather, biofuel policies and speculators etc. Unfortunately, empirical study in this area is scarce, and the underlying reasons behind the soaring commodity prices require further in-depth study.

Table A2 shows the unit root tests results using ADF and PP tests on the level and the first difference of all the price series for the entire sample period from 1986-2010. The SIC is employed for determining the optimal number of lags. The period is not divided by every five years because the aim now is to detect and analyze the possibility of a long run relationship. Should the analysis be broken up into sub-periods as was done with the volatility modeling section, it may not yield enlightening results. Based on the unit root test results, it can be established that at a significance level of $1 \%$, all price series are non-stationary in level and integrated of the same order, $\mathrm{I}(1)$. This is also consistent with the stationarity found in the return series.

Given the integrated series of the same order, we proceed to investigate the long-run relationship between all the possible commodity pairs using the Engle-Granger cointegration test. As the nature of the relationship is only bivariate and multiple cointegrating relationships are not of interest, this method is chosen above the Johansen cointegration test (Johansen \& Juselius, 1990). Table 6 summarizes the results and the numbers in bold indicate the cointegrated commodity pairs. Cointegration between commodity pairs such as corn and wheat, soybean and wheat, as well as soybean and corn are found and supported by prior research papers such as Arendarski and Postek (2012). This phenomenon could be attributed partially to "herd behavior" where traders will be alternatively bullish or bearish on all commodities for no plausible economic reason as they believe that agricultural commodity prices tend to move together (Pindyck \& Rotemberg, 1990). The weak cointegrating relationships between Brent and Wheat, Brent and Soybean, and Gold and Soybean are also identified at the significance level of $10 \%$. However, a long-term equilibrium between gold and crude oil found by Le and Chang (2011) and Zhang and Wei (2010) is not evident in our sample. Furthermore, the strong correlations between gold and silver are found to not translate into the long-run relationship, which is consistent with Sari et al. (2010).

Table 6. Engle-Granger cointegration results

\begin{tabular}{lccccc}
\hline \multicolumn{7}{c}{} \\
\hline Gold & Silver & Wheat & Corn & Soybean \\
\hline Brent & -2.336 & -1.678 & $-2.787 *$ & -2.550 & $-2.753^{*}$ \\
Gold & & -2.466 & -2.016 & -2.306 & $-2.607^{*}$ \\
Silver & & -1.717 & -1.800 & -1.777 \\
Wheat & & & $-4.736 * * *$ & $-4.344^{* * *}$ \\
Corn & & & & $-4.257^{* * *}$ \\
\hline
\end{tabular}

Note. $* * *, * *$, and $*$ represent significance levels at $1 \%, 5 \%$, and $10 \%$, respectively.

Once cointegration relationships are established, the error correction model could be employed to test the existence and direction of the short-run and long-run causality. The lag length is determined by the SIC in the VAR model. The Granger causal relationships based on the Granger causality test results are summarized in Figure 3. A short-run Granger causality running from Soybean to Wheat, Wheat to Corn, Soybean to Corn, and Soybean to Gold is observed. A bi-directional Granger causal relationship between Wheat and Brent, and that between Soybean and Brent also exist in the short-run. Next turn to the long-run causality, we find that the short-run Granger causality also exists in the long run (Note 9). 


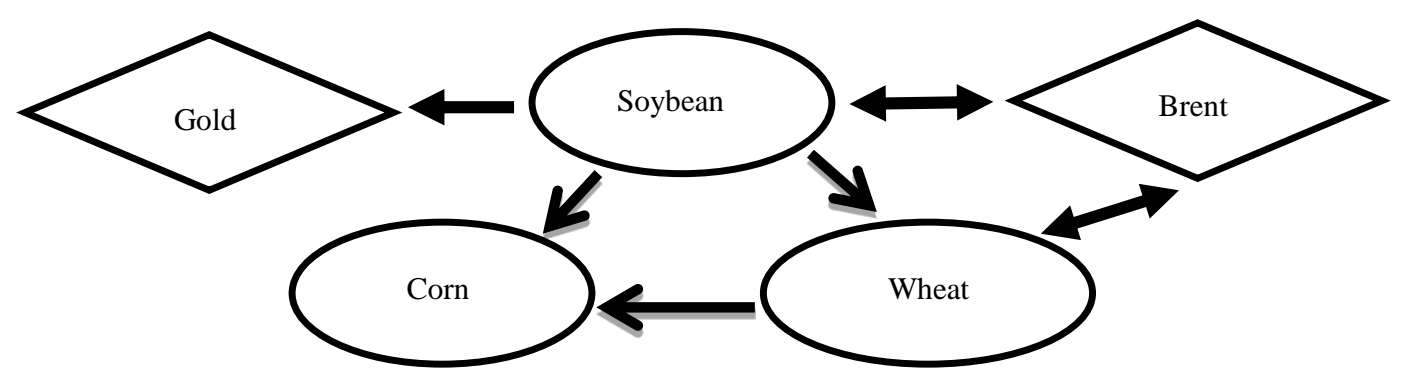

Figure 3. Causality relationship between cointegrated commodities

With regards to the three agricultural commodity pairs, the Granger causality could be explained by the crop rotation methods endorsed by U.S. Department of Agriculture (USDA) and used by farmers in main producer countries such as the US and South America. Common convention crop rotations such as the alternation of soybeans as well as the three year rotation of corn-soybean-wheat are carried out because these methods replenish the much needed nitrogen levels in the soil. As farmers will definitely need to plant soybeans at one point or another in order to sustain annual agricultural production, the total acreage of land used to plant soybean can be used to predict the amount of acreage that can be used to plant corn and subsequently wheat in some cases. This also allows for an estimation of the quantity and prices of corn and wheat for the subsequent year.

It is, however, important to note that Granger causality is a concept that should be used with care. Granger Causality is a concept that is based on prediction, and does not necessarily mean "real causality", even though "real causality" may be captured within the result. The fact that a variable Granger causes another variable merely means that the past values of one variable have some information that could help predict the future values of another variable (Saghaian, 2010).

\section{Conclusions and Policy Implications}

This study investigates price volatility of Brent and five other commodities and their relationships in the long run. Besides adding to the sparse literature on the comparative study of commodities' prices, the major contribution of this paper is that we conducted an extensive study on the volatility, cointegration and causation of prices of our target commodities. Conclusively, this study finds that Brent price is not always more volatile than the prices of precious metals and agricultural commodities. It also finds that Brent is cointegrated with soybean and wheat, and the Granger causality relationship is bilateral.

First, through modeling the volatility of returns of the six commodities using various GARCH variants, we find evidence of volatility persistence. Moreover, we find that the proposition that negative shocks induce a larger impact on volatility than positive shocks is not always true. For instance, with reference to soybean, results in Periods 1986-1990 and 1991-1995 showed that positive shocks induce a larger impact on volatility.

Second, the mean conditional volatility showed that the myth that crude oil is always more volatile than other commodities can be debunked as results showed that Wheat and Corn turned out to have a higher mean value of conditional volatility than Brent in the last five year period.

Last, further in-depth analysis on the correlation, cointegration and causality on the commodities was conducted. Since the correlation measure only indicates that the returns of the commodity pairs rise and fall in synchrony, Engle-Granger cointegration test was deployed throughout the entire period to find a long-run cointegrating relationship. It finds that six pairs of commodities exhibited long-run equilibrium over the 25 years period: Brent and Wheat, Brent and Soybean, Gold and Soybean, Wheat and Soybean, Wheat and Corn, Soybean and Corn. These results can be useful to investors or traders interested in pair trading. This is because there is an opportunity of arbitrage and they can short a particular commodity and long the other with reason to believe that the spread would revert to the mean eventually. The error correction model also revealed the percentage at which one commodity corrects to the equilibrium at the end of each day, and the direction of the causality between the commodity pairs.

The empirical results in this study have managed to answer the three questions that were posed in the introduction. However, future researches could include other subgroups (i.e., non-ferrous metals such as aluminum, nickel etc.) or even more commodities to fortify the notions. In addition, future work can also evaluate volatility spillover effects in the commodity markets. Empirical research on factors causing soaring commodity prices is also worth a study, especially China's growth and influence on the commodity prices. 


\section{References}

Agnolucci, P. (2009). Volatility in crude oil futures: A comparison of the predictive ability of GARCH and implied volatility models. Energy Economics, 31(2), 316-321. https://doi.org/10.1016/j.eneco.2008.11.001

Arendarski, P., \& Postek, L. (2012). Cointegration based trading strategy for soft commodities market. Working Papers 2012-02, Faculty of Economic Sciences, University of Warsaw.

Bentzen, J. (2007). Does OPEC influence crude oil prices? Testing for co-movements and causality between regional crude oil prices. Applied Economics, 39, 1375-1385. https://doi.org/10.1080/00036840600606344

Bollerslev, T. (1986). Generalized autoregressive conditional heteroskedasticity. Journal of Econometrics, 31, 307-327. https://doi.org/10.1016/0304-4076(86)90063-1

BP. (2012). Statistical Review of World Energy 2012. British Petroleum, London.

Calvo-González, O., Shankar, R., \& Trezzi, R. (2010). Are commodity prices more volatile now? A Long-Run Perspective (October 1, 2010). World Bank Policy Research Working Paper Series.

Cheong, C. W. (2009). Modeling and forecasting crude oil markets using ARCH-type models. Energy Policy, 37(6), 2346-2355. https://doi.org/10.1016/j.enpol.2009.02.026

Clem, A. (1985). Commodity price volatility: Trends during 1975-84. Monthly Lab. Rev., 108, 17.

Conrad, C., \& Haag, B. R. (2006). Inequality constraints in the fractionally integrated GARCH model. Journal of Financial Econometrics, 4(3), 413-449. https://doi.org/10.1093/jjfinec/nbj015

Ding, Z., Granger, C. W. J., \& Engle, R. F. (1993). A long memory property of stock market returns and a new model. Journal of Empirical Finance, 1, 83-106. https://doi.org/10.1016/0927-5398(93)90006-D

Engle, R. F. (1982). Autoregressive conditional heteroskedasticity with estimates of the variance of United Kingdom inflation. Econometrica, 50, 987-1007. https://doi.org/10.2307/1912773

Engle, R. F., \& Yoo, B. S. (1987). Forecasting and testing in co-integrated systems. Journal of Econometrics, 35, 143-159. https://doi.org/10.1016/0304-4076(87)90085-6

Engle, R. F., \& Granger, C. W. J. (1987). Co-integration and error correction: Representation, estimation and testing. Econometrica, 55, 251-276. https://doi.org/10.2307/1913236

Engle, R. F., \& Ng, V. (1993). Measuring and testing the impact of news on volatility. Journal of Finance, 48, 1749-78. https://doi.org/10.1111/j.1540-6261.1993.tb05127.x

Erten, B., \& Ocampo, J.A. (2013). Super cycles of commodity prices since the mid-nineteenth century. World Development, 44, 14-30. https://doi.org/10.1016/j.worlddev.2012.11.013

Fattouh, B. (2007). WTI benchmark temporarily breaks down: is it really a big deal? Middle East Economic Survey, 49.

Fattouh, B. (2010). The dynamics of crude oil price differentials. Energy Economics, 32, 334-342. https://doi.org/10.1016/j.eneco.2009.06.007

Franses, P. H., \& Van Dijk, D. (2000). Non-Linear Time Series Models in Empirical Finance. Cambridge: Cambridge University Press. https://doi.org/10.1017/CBO9780511754067

Gileva, T. (2010). Econometrics of crude oil markets. Master Thesis, Universite Paris 1 Pantheon-Sorbonne.

Glosten, L. R., Jagannathan, R., \& Runkle, D. E. (1993). On the relation between the expected value and the volatility of the nominal excess return on stocks. Journal of Finance, 48(5), 1779-1801. https://doi.org/10.1111/j.1540-6261.1993.tb05128.x

Granger, C. W. J. (1988). Some recent development in a concept of causality, Journal of Econometrics, 39(1-2), 199-211. https://doi.org/10.1016/0304-4076(88)90045-0

Gulen, S. G. (1997). Regionalization in the world crude oil market. The Energy Journal, 18, 109-126. https://doi.org/10.5547/issn0195-6574-ej-vol18-no2-6

Hansen, P., \& Lunde, A. (2004). A Forecast Comparison of Volatility Models: Does Anything Beat a GARCH(1,1) Model? Journal of Applied Econometrics, 20, 873-889. https://doi.org/10.1002/jae.800

Hammoudeh, S., Sari, R., \& Ewing, B. T. (2008). Relationships among strategic commodities and with financial variables: A new look. Contemporary Economic Policy, 27(2), 251-264. https://doi.org/10.1111/j.1465-7287.2008.00126.x 
Hooker, M. A. (2002). Are oil shocks inflationary? A symmetric and nonlinear specifications versus changes in regime. Journal of Money, Credit and Banking, 34, 540-561. https://doi.org/10.1353/mcb.2002.0041

Hunt, B. (2006). Oil price shocks and the U.S. stagflation of the 1970s: Some insights from GEM. The Energy Journal, 27, 61-80. https://doi.org/10.5547/ISSN0195-6574-EJ-Vol27-No4-3

Jacks, D., O'Rourke, K., \& Williamson, J. (2011). Commodity price volatility and world market integration since 1700. Review of Economics and Statistics, 93(3), 800-813. https://doi.org/10.1162/REST_a_00091

Jaeger, M. (2012). Does gold set the price for oil? The Washington Times.

Kang, S. H., Kang, S. M., \& Yoon, S. M. (2009). Forecasting volatility of crude oil markets. Energy Economics, 31(1), 119-125. https://doi.org/10.1016/j.eneco.2008.09.006

Kao, C. W., \& Wan, J. Y. (2012). Price discount, inventories and the distortion of WTI benchmark. Energy Economics, 34, 117-124. https://doi.org/10.1016/j.eneco.2011.03.004

Kaufmann, R. K., \& Ullman, B. (2009). Oil prices, speculation, and fundamentals: Interpreting causal relations among spot and futures prices. Energy Economics, 31, 550-558. https://doi.org/10.1016/j.eneco.2009.01.013

Kuper, G. H. (2002). Measuring oil price volatility. Research Report 02C43, University of Groningen, Research Institute SOM (Systems, Organisations and Management). https://doi.org/10.2139/ssrn.316480

Le, T. H., \& Chang, Y. (2011). Oil and gold: correlation or causation? MPRA Paper 31795, University Library of Munich, Germany.

Le, T. H., \& Chang, Y. (2012). Oil price shocks and gold returns. Economie Internationale, 131, 71-104. https://doi.org/10.1016/s2110-7017(13)60055-4

Le, T. H., \& Chang, Y. (2016). Dynamics between strategic commodities and financial variables: Evidence from Japan. Resources Policy, 50, 1-9. https://doi.org/10.1016/j.resourpol.2016.08.006

Melvin, M., \& Sultan, J. (1990). South African political unrest, oil prices, and the time varying risk premium in the fold futures market. Journal of Futures Markets, 10, 103-111. https://doi.org/10.1002/fut.3990100202

Moledina, A. A., Roe, T. L., \& Shane, M. (2004). Measuring commodity price volatility and the welfare consequences of eliminating volatility. In Annual meeting, August (pp. 1-4).

Narayan, P. K., \& Liu, R. (2011). Are shocks to commodity prices persistent? Applied Energy, 88(1), 409-416. https://doi.org/10.1016/j.apenergy.2010.07.032

Narayan, P. K., \& Narayan, S. (2007). Modelling oil price volatility. Energy Policy, 35, 6549-6553. https://doi.org/10.1016/j.enpol.2007.07.020

Narayan, P. K., Narayan, S., \& Zheng, X. (2010). Gold and oil futures markets: Are markets efficient? Applied Energy, 87(10), 3299-3303. https://doi.org/10.1016/j.apenergy.2010.03.020

Nelson, D. B. (1991). Conditional heteroskedasticity in asset returns: A new approach. Econometrica, 59(2), 347-370. https://doi.org/10.2307/2938260

Nelson, D. B., \& Cao, C. Q. (1992). Inequality constraints in the univariate GARCH model. Journal of Business and Economic Statistics, 10(2), 229-235. https://doi.org/10.1080/07350015.1992.10509902

Nomikos, N. K., \& Pouliasis, P. K. (2011). Forecasting petroleum futures markets volatility: The role of regimes and market conditions. Energy Economics, 33(2), 321-337. https://doi.org/10.1016/j.eneco.2010.11.013

Pagan, A., \& Schwert, G. W. (1990). Alternative models for conditional volatility. Journal of Econometrics, 45, 267-290. https://doi.org/10.1016/0304-4076(90)90101-X

Pindyck, R., \& Rotemberg, J. (1990). The excess co-movement of commodity prices. Economic Journal, 100, 1173-1189. https://doi.org/10.2307/2233966

Plourde, A., \& Watkins, G. C. (1998). Crude oil prices between 1985 and 1994: how volatile in relation to other commodities? Resource and Energy Economics, 20(3), 245-262. https://doi.org/10.1016/S0928-7655(97)00027-4

Ramey, G., \& Ramey, V. A. (1995). Cross-country evidence on the link between volatility and growth. American Economic Review, 85(5), 1138-1151.

Rodrick, D. (1999). Where did all the growth go? External shocks, social conflict and growth collapse. Journal of Economic Growth, 4(4), 385-412. https://doi.org/10.1023/A:1009863208706 
Regnier, E. (2007). Oil and energy price volatility. Energy Economics, 29(3), 405-427. https://doi.org/10.1016/j.eneco.2005.11.003

Saghaian, S. H. (2010). The impact of the oil sector on commodity prices: Correlation or causation? Journal of Agricultural and Applied Economics, 42(3), 477-485. https://doi.org/10.1017/S1074070800003667

Sari, R., Hammoudeh, S., \& Soytas, U. (2010). Dynamics of oil price, precious metal prices, and exchange rate. Energy Economics, 32(2), 351-362. https://doi.org/10.1016/j.eneco.2009.08.010

Soytas, U., Sari, R., Hammoudeh, S., \& Hacihasanoglu, E. (2009). World oil prices, precious metal prices and macroeconomy in Turkey. Energy Policy, 37, 5557-5566. https://doi.org/10.1016/j.enpol.2009.08.020

Teräsvirta, T. (2008). An introduction to univariate GARCH Models. In T. G. Andersen, R. A. Davis, J. P .Kreiss, $\&$ T. Mikosch (Eds.), Handbook of Financial Time Series. New York: Springer.

Wang, M. L. Wang, C. P., \& Huang, T. Y. (2010). Relationships among oil price, gold price, exchange rate and international stock markets. International Research Journal of Finance and Economics, 47, 82-91.

Zakoian, M. (1994). Threshold heteroscedastic models. Journal of Economic Dynamics and Control, 18, 931-955. https://doi.org/10.1016/0165-1889(94)90039-6

Zhang, Y. J., \& Wei, Y. M. (2010). The crude oil market and the gold market: Evidence for co-integration,

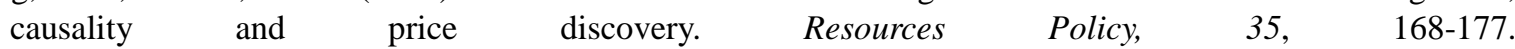
https://doi.org/10.1016/j.resourpol.2010.05.003

\section{Notes}

Note 1. The three most common types of crude oil are the West Texas Intermediate (WTI) and Brent-Blend (Brent) and the Dubai-Fateh (Dubai). They represent the Middle East, Europe and Eurasia, and North America regions respectively (Bentzen, 2007; Fattouh, 2010; Kaufmann \& Ulman, 2009). The oil production in these three markets accounts for more than seventy per cent of oil production in 2011 (BP, 2012).

Note 2. OAPEC consists of Arab members of Organization of Petroleum Exporting Countries (OPEC), plus Egypt, Syria and Tunisia.

Note 3. Yom Kippur War or the Ramadan War was a war between Israel and a group of Arab countries led by Egypt and Syria. The war occurred during October 6 to October 24, 1973. The members of the OAPEC then ceased shipping petroleum to nations that had supported Israel.

Note 4. Brent and WTI used to be the best of partners. Wherever one went, the other soon followed in near perfect harmony. However, due to increasing outputs from areas such as North Dakota and Canada, WTI price has been disconnected from the prices of other benchmarks since 2006 (Kao \& Wan, 2012; Fattouh, 2007). Furthermore, Brent has replaced WTI as the benchmark for oil forecasts by the US Energy Agency in 2012, with the entity citing divergence of WTI prices and the increasing average daily volume of Brent on ICE Futures Europe overtaking that of WTI on NYMEX. Given the above considerations, this study chooses to use Brent prices over WTI.

Note 5. Since a short time span of every five year is used in the volatility modeling, break points will not be a major problem.

Note 6. The ARCH test has been applied to autoregressive models with various lags and tested for the residuals with lags up to 30 . All the results show the existence of the ARCH effect in the return series.

Note 7. The TGARCH is also known as the GJR-GARCH model.

Note 8. The GARCH(1,1) model for oil series is consistent with Agnolucci (2009) and Cheong (2009), but different from the CGARCH (Kang et al., 2009) or a Markov-switching GARCH model (Nomikos and Pouliasis, 2011) used by some other scholars.

Note 9. The Granger causality test results and the cointegrating relationships of the six pairs are available from authors upon request. The cointegrating relationships confirm the existence of long-run equilibrium, as all the coefficients are significantly different from zero at the $1 \%$ level. 


\section{Appendix}

\section{Table A1. Correlation matrix}

\begin{tabular}{|c|c|c|c|c|c|c|}
\hline \multicolumn{7}{|c|}{ Correlation Matrix - 1986/1990 } \\
\hline & Brent & Gold & Silver & Wheat & Soybean & Corn \\
\hline Brent & 1.0000 & & & & & \\
\hline Gold & 0.1152 & 1.0000 & & & & \\
\hline Silver & 0.0790 & 0.5003 & 1.0000 & & & \\
\hline Wheat & 0.0291 & -0.0059 & -0.0447 & 1.0000 & & \\
\hline Soybean & 0.0220 & 0.0529 & -0.0420 & 0.3032 & 1.0000 & \\
\hline Corn & 0.0136 & -0.0074 & -0.0159 & 0.3476 & 0.5962 & 1.0000 \\
\hline \multicolumn{7}{|c|}{ Correlation Matrix - 1991/1995 } \\
\hline & Brent & Gold & Silver & Wheat & Soybean & Corn \\
\hline Brent & 1.0000 & & & & & \\
\hline Gold & 0.2327 & 1.0000 & & & & \\
\hline Silver & 0.0229 & 0.4707 & 1.0000 & & & \\
\hline Wheat & -0.0299 & -0.0191 & -0.0369 & 1.0000 & & \\
\hline Soybean & -0.0176 & 0.0559 & -0.0147 & 0.2483 & 1.0000 & \\
\hline Corn & -0.0425 & 0.0339 & -0.0043 & 0.2836 & 0.6379 & 1.0000 \\
\hline \multicolumn{7}{|c|}{ Correlation Matrix - 1996/2000 } \\
\hline & Brent & Gold & Silver & Wheat & Soybean & Corn \\
\hline Brent & 1.0000 & & & & & \\
\hline Gold & 0.0455 & 1.0000 & & & & \\
\hline Silver & 0.0211 & 0.2909 & 1.0000 & & & \\
\hline Wheat & 0.0651 & 0.0782 & -0.0034 & 1.0000 & & \\
\hline Soybean & 0.0283 & 0.0608 & -0.0118 & 0.4654 & 1.0000 & \\
\hline Corn & 0.0467 & -0.0131 & 0.0470 & 0.0832 & 0.0836 & 1.0000 \\
\hline \multicolumn{7}{|c|}{ Correlation Matrix - 2001/2005 } \\
\hline & Brent & Gold & Silver & Wheat & Soybean & Corn \\
\hline Brent & 1.0000 & & & & & \\
\hline Gold & 0.0718 & 1.0000 & & & & \\
\hline Silver & 0.0243 & 0.3905 & 1.0000 & & & \\
\hline Wheat & 0.0662 & 0.0344 & 0.0585 & 1.0000 & & \\
\hline Soybean & 0.0507 & 0.0182 & 0.0280 & 0.2970 & 1.0000 & \\
\hline Corn & 0.0385 & 0.0179 & 0.0408 & 0.3107 & 0.3698 & 1.0000 \\
\hline \multicolumn{7}{|c|}{ Correlation Matrix - 2006/2010 } \\
\hline & Brent & Gold & Silver & Wheat & Soybean & Corn \\
\hline Brent & 1.0000 & & & & & \\
\hline Gold & 0.3265 & 1.0000 & & & & \\
\hline Silver & 0.2674 & 0.4763 & 1.0000 & & & \\
\hline Wheat & 0.1781 & 0.1340 & 0.0681 & 1.0000 & & \\
\hline Soybean & 0.3287 & 0.1625 & 0.1025 & 0.4462 & 1.0000 & \\
\hline Corn & 0.2704 & 0.1668 & 0.1155 & 0.5290 & 0.6251 & 1.0000 \\
\hline
\end{tabular}

Table A2. Unit root test results for prices

\begin{tabular}{|c|c|c|c|c|c|c|c|c|}
\hline & \multicolumn{4}{|c|}{ ADF Test } & \multicolumn{4}{|l|}{ PP Test } \\
\hline & Level & & First diff & & Level & & First dif & \\
\hline Brent & -0.407 & $(0.906)$ & -81.653 & $(0.000)$ & -0.531 & $(0.883)$ & -81.738 & $(0.000)$ \\
\hline Gold & 2.046 & $(1.000)$ & -22.699 & $(0.000)$ & 1.934 & $(1.000)$ & -84.095 & $(0.000)$ \\
\hline Silver & -0.253 & $(0.929)$ & -29.686 & $(0.000)$ & -0.103 & $(0.947)$ & -94.493 & $(0.000)$ \\
\hline Wheat & -1.774 & (0.394) & -45.974 & $(0.000)$ & -1.872 & $(0.346)$ & -92.330 & $(0.000)$ \\
\hline Corn & -0.741 & $(0.835)$ & -81.346 & $(0.000)$ & -0.796 & $(0.820)$ & -81.321 & $(0.000)$ \\
\hline Soybean & -1.112 & $(0.713)$ & -85.397 & $(0.000)$ & -1.246 & $(0.657)$ & -85.453 & $(0.000)$ \\
\hline
\end{tabular}

Note. In parenthesis are p-values.

\section{Copyrights}

Copyright for this article is retained by the author(s), with first publication rights granted to the journal.

This is an open-access article distributed under the terms and conditions of the Creative Commons Attribution license (http://creativecommons.org/licenses/by/4.0/). 